\title{
SINKRETIZMI BAŠTINSKIH USTANOVA U BOSNI I HERCEGOVINI: PRILOG NAUČNOJ VALORIZACIJI NJIHOVIH HISTORIJSKIH VEZA I AKTUELNIH ODNOSA
}

\section{Prof. dr. Lejla Kodrić Zaimović}

Odsjek za komparativnu književnost i bibliotekarstvo, Katedra za bibliotekarstvo, Filozofski fakultet Univerziteta u Sarajevu, Sarajevo, Bosna i Hercegovina

Department of Comparative Literature and Library Sciences, Department of Library Sciences, Faculty of Philosophy, University of Sarajevo, Sarajevo, Bosnia and Herzegovina

lejla.kodric-zaimovic@ff.unsa.ba; lejla.kodric.zaimovic@gmail.com

\begin{abstract}
Sažetak
Tradicija, kao i aktuelna praksa baštinskih ustanova u Bosni i Hercegovini, kao svoje kontinuirano obilježje pokazuje odlike sličnih razvojnih obrazaca, ali i tekućih praksi između najdominantnijih predstavnika baštinskih ustanova današnjice - arhiva, biblioteka i muzeja. Konvergirane prakse baštinskih ustanova uopće pronalaze se kroz cjelokupnu njihovu historiju, kako na općem, globalnom, tako i na bosanskohercegovačkom, dakle, partikularnom nivou. lako su posve vidljivi paralelizmi, ali i specifičnosti u tradiciji te u aktuelnom djelovanju baštinskih ustanova u Bosni i Hercegovini, u bosanskohercegovačkoj naučnoj publicistici očita je praznina u bavljenju uporednim proučavanjem međuodnosa najrazvijenih baštinskih ustanova ovog prostora, kako u njihovoj dijahronijskoj, tako i u sinhronijskoj perspektivi. I pored toga što su jedinstvena historijska ishodišta, kao i kasnija oslanjanja te konvergiranje ustanova jednih s drugima potpuno razvidna i na primjerima prošlosti bosanskohercegovačkih biblioteka, arhiva i muzeja, stvarni sinkretizam ustanova danas je još očitiji - nerijetko potaknut promjenama u širem informacijsko-komunikacijskom okruženju, ali i izmijenjenim očekivanjima korisnika. Interdisciplinarni pojam sinkretizma u predmetnom radu koristi se u svojem prenesenom smislu, opisujući procese razvoja baštinskih ustanova iz zajedničkih ishodišta, ali i njihova kasnija približavanja kroz pojave kakve su: zamjenska uloga jedne baštinske ustanove do formiranja druge, jedinstveno čuvanje baštinske građe bez institucionalne podjele, objedinjeno djelovanje arhiva, biblioteka i muzeja "pod jednim krovom", sve do zajedničkih digitalizacijskih projekata, okupljanja baštinske profesije unutar zajedničkih profesionalnih organizacija, kao i, na kraju, pitanja zajedničkih akademskih programa, koji pod generičkim pojmom informacijskih nauka integriraju tri istaknute baštinske discipline i u ovim okvirima. Stoga predmetni rad ima za cilj doprinijeti naučnoj valorizaciji veza između bosanskohercegovačkih baštinskih ustanova i profesija kako u prošlosti, tako i sve do danas.
\end{abstract}

Ključne riječi: baštinske ustanove, arhivi, biblioteke i muzeji, sinkretizmi, paralelizmi, Bosna i Hercegovina

\section{Uvodne napomene ili Sinkretizam kao kontinuum djelovanja baštinskih ustanova u Bosni i Hercegovini}

Jedinstveno historijsko ishodište baštinskih ustanova - prvenstveno arhiva, biblioteka i muzeja - prepoznatljivo još unutar njihovog najranijeg pojavljivanja kod srednjoistočnih starovjekovnih civilizacija, ponavljajući je obrazac njihova razvoja i u prostorno i vremenski udaljenim civilizacijama i kontekstima te posve drugačijim lokalnim praksama i običajima, uključujući i slučaj Bosne i Hercegovine, u kojoj vremenski rasponi nastanka i razvojni obrasci tri temeljne institucije nacionalnog pamćenja - arhiva, biblioteka i muzeja - također pokazuju odlike razvojnih paralelizama, kako u počecima njihove institucionalizacije, tako i sve do danas. Konvergencija, odnosno približavanje i/ili ujedinjenje mjesta pohrane artefakata koje u savremenim određenjima prepoznajemo kao arhivsku, bibliotečku i muzejsku građu, jednako kao i praksi rukovođenja spomenutom građom, najraniji je oblik postojanja baštinskih ustanova, s tim da se konvergiranje baštinskih ustanova - poput metaforičke ponornice - kontinuirano uočava tokom višemilenijskog postojanja baštinskih ustanova, smjenjujući se s povremenim periodima divergiranja ili udaljavanja njihovih praksi, što su, ipak, prije izuzeci nego standardizirane prakse, osobito povezane s osamostaljenjem arhivske, bibliotečke i muzejske djelatnosti u zasebne, prepoznatljive strukovne i akademske discipline tokom 19. st. 
Ipak, historijski gledano, periodi konvergiranja ili zbližavanja baštinskih ustanova brojniji su i trajniji od onih divergentnih, što svjedoče ne samo najraniji primjeri nastajanja arhiva, biblioteka i muzeja već i drugi brojni primjeri iz zajedničke baštinske prošlosti, poput, recimo, prakse evropskih kabineta rijetkosti iz perioda humanizma i renesanse, kao egzemplarnih slučajeva jedinstvenog okupljanja arhivske, bibliotečke i muzejske građe u doba prije fizičkog osamostaljenja ustanova, a, posebno, i prakse današnjice, osobito unutar brojnih primjera sinkretskih baštinskih ustanova koje svojim nazivima i praksom objedinjuju, recimo, dva ili, pak, sva tri najizraslija tipa baštinskih ustanova ili, na koncu, u slučaju, digitalne pojavnosti ustanova pamćenja, unutar kojih je stvarno fizičko porijeklo artefakata za krajnjeg korisnika irelevantno, sve dok je digitalizirani ili izvorno digitalni objekt baštine dostupan na Mreži.

Očito je, sinkretizmi i paralelizmi između različitih tipova ustanova baštine i u dijahronijskoj i u sinhronijskoj perspektivi pojavljuju se na brojnim razinama: na razinama fizičkog objedinjavanja ustanova, zatim u primjerima u kojima jedan tip ustanove preuzima ulogu druge / ostalih baštinskih ustanova - u slučajevima historijskog nepostojanja ili nerazvijenosti njihovih uobičajenih manifestacija - ali jednako se tako paralelizmi uočavaju i u srodnom razvoju profesionalnih i zakonodavnih okvira, akademskih disciplina ili, pak, u jedinstvenim strategijama implementiranja novih informacijsko-komunikacijskih tehnologija, a u kontekstu savremene prakse baštinskih ustanova.

Stoga, konvergiranje baštinskih ustanova, od njihove inicijalne pojavnosti pa sve do danas, pokazatelj je nedjeljivosti njihovih ciljeva i poslanja, i pored očiglednih razlika u današnjoj praksi arhiva, biblioteka i muzeja, s temeljnom objedinjujućom misijom - očuvanjem nacionalnog pamćenja. Pa tako, i kad se prakse, alati i profesionalni standardi triju istaknutih baštinskih profesija današnjice - arhivistike, bibliotekarstva i muzeologije - gdjegod i očiglednije razlikuju, društveni učinci profesija i pripadajućih ustanova, kao i percepcija javnosti, ostaju gotovo jedinstveni - tim prije što je digitalno okruženje današnjice konvergenciju baštinskih ustanova dovelo do samog vrhunca. Zajednička historijska ishodišta i posljedični paralelizmi njihova kasnijeg razvoja kontinuum su djelovanja ustanova baštine uočljiv u najrazličitijim vremenskim i prostornim okvirima, gotovo njihov univerzalni princip postojanja, neovisno o lokalnim kontekstima i praksama, a što je, očito, slučaj i s Bosnom i Hercegovinom. Predmetni rad prilog je u Bosni i Hercegovini još uvijek nepostojećoj naučnoj studiji ili monografiji o komparativnim odnosima tri istaknute baštinske discipline, o njihovim zajedničkim ishodištima te o kasnijim "susretanjima" i preplitanjima, kao i o sta- nju te uporednim razvojnim perspektivama baštinskih profesija u Bosni i Hercegovini danas. ${ }^{1}$

\section{Bosanskohercegovačka kultura srednjeg vijeka: ishodište sinkretizma baštinskih ustanova}

Baštinska djelatnost u Bosni i Hercegovini djelatnost je s dugom tradicijom (ne podrazumijevajući nužno i njezinu istovremenu formalnu institucionalizaciju), što se posebno odnosi na onu bibliotečku, ali i djelatnost sa zasebnim, prepoznatljivim tokovima historijskog razvoja bibliotekarstva, arhivistike i muzeologije, njihove institucionalizacije, profesionalnih, zakonodavnih i akademskih okvira, riječju, u pitanju su tradicije međusobno povezane, ali i osamostaljene u tri izdiferencirane profesije, za koje se pitanje saradnje i konvergencije oduvijek, a danas, u vremenu savremenih informacijsko-komunikacijskih tehnologija i generičkog okvira informacijskih nauka kao trima profesijama nadređene akademske discipline - i posebno uspostavlja kao jedno od gorućih.

Za tri istaknute baštinske profesije trenutno u Bosni i Hercegovini ne postoji cjelovit akademski okvir -

\footnotetext{
Na praznine u naučnom bavljenju ovim fenomenima, kao i na potrebu za ovakvim studijama, pažnju je skrenula autorica predmetnog rada u koautorskoj knjizi Kratka historija kulture Bošnjaka autora Nirhe Efendić, Ibrahima Krzovića, Almedine Čengić, Merime Čaušević i Lejle Kodrić Zaimović (IUS: Simurg Media, 2018). U poglavlju Baština, baštinske ustanove i nacionalno pamćenje autorica Lejla Kodrić Zaimović bavi se uporednom historijom razvoja temeljnih baštinskih ustanova u Bosni i Hercegovini - arhiva, biblioteka i muzeja - i to na strukovnoj, akademskoj i zakonodavnoj razini, kao i aktuelnostima u baštinskim profesijama u Bosni i Hercegovini danas, s tim da, s obzirom na širi izdavački okvir Edicije Bošnjaci, spomenuta knjiga akcentira doprinos bošnjačke kulture i naslijeđa Bošnjaka razvoju baštinskih djelatnosti u Bosni i Hercegovini. Za razliku od toga predmetni rad Sinkretizmi baštinskih ustanova u Bosni i Hercegovini: prilog naučnoj valorizaciji njihovih historijskih veza i aktuelnih odnosa dijelom sintetizira ranije autoricino naučno bavljenje odabranim fenomenom, ali i posmatra bosanskohercegovačku kulturu integrirano te, što valja posebno naglasiti, tematizira jedan važan, izdvojen fenomen u višestoljetnoj zajedničkoj historiji baštinskih ustanova u Bosni i Hercegovini, a to je njihov sinkretizam. Sinkretizam baštinskih ustanova danas prepoznajemo ne samo u dijeljenju istih ili sličnih razvojnih obrazaca, međusobnom oslanjanju institucija jednih na druge ili zamjenjivanju međusobnih uloga i funkcija u situacijama nepostojanja izvjesnog tipa bašinske ustanove, o čemu historija bosanskohercegovačkih ustanova baštine zorno svjedoči, već sinkretizam prepoznajemo i u zajedničkim baštinskim praksama danas, u umrežavanju, u jedinstvenim ili povezanim profesionalnim organizacijama, u konkretnim ustanovama koje integriraju dva ili više ustaljenih tipova baštinske ustanove, potom u sličnim zakonskim regulativama, u dijeljenju ekspertnih znanja, potom u dijeljenju napora te razmjeni profesionalnih znanja na uvođenju informacijskokomunikacijskih tehnologija u službe ustanova, u korištenju tehnologija, opreme i s njima povezanih vještina putem tzv. outsourcinga, ali i na inim drugim primjerima koji dokazuju kontinuum sinkretskih odnosa u baštinskim ustanovama Bosne i Hercegovine.
} 
izuzev onoga koji je u vezi s akademskim obrazovanjem bibliotekara - a tradicionalno su se izučavale unutar već etabliranih nauka ili naučnih disciplina poput historije, kulturne historije, historije knjige i institucija, historije umjetnosti, nerijetko i uz studije književnosti, a u Bosni i Hercegovini djelimično i unutar orijentalne filologije, vezujući se za ishodišta institucionalizacije biblioteka u Bosni i Hercegovini te javnog pristupa knjizi, što su pojave začete $s$ osmanskom kulturom u Bosni i Hercegovini. I bez jedinstvenog akademskog okvira za sve tri istaknute baštinske discipline, postojeći akademski programi konvergiraju, pa čak i integriraju akademsko proučavanje baštinskih profesija, bilo pod generičkim okvirom informacijskih nauka, bilo unutar nekog drugog, u lokalnom kontekstu realiziranog akademskog nazivlja. Stoga je, kao i na globalnim razinama, bavljenje baštinskim ustanovama u Bosni i Hercegovini necjelovito bez razumijevanja njihovih historijskih ishodišta i razvojnih pravaca, jednako kao i bez razumijevanja ovdašnjih aktuelnosti u arhivskoj, bibliotečkoj i muzejskoj djelatnosti. U tom smislu, niz je procesa i pojava iz dalje ili recentnije bosanskohercegovačke prošlosti na čijem se tragu uočavaju konvergirane prakse ovdašnjih baštinskih ustanova, a koji određuju i savremenu praksu baštinskih ustanova u Bosni i Hercegovini.

Suštinski, najprije valja uspostaviti razliku između začetaka baštinske djelatnosti u Bosni i Hercegovini i njezinog funkcioniranja prije formalne organizacije službi baštinskih ustanova u zemlji, na jednoj, odnosno, njezine formalne institucionalizacije, na drugoj strani, što su procesi, naravno, međusobno povezani, ali i takvi da se odvijaju unutar različitih, vremenski vrlo razuđenih perioda. Djelatnost baštinjenja, sabiranja, kolekcionarstva, za koju postoje tragovi organiziranog djelovanja u Bosni i Hercegovini, datira još od srednjovjekovnog perioda, odnoseći se na kancelarijsko proizvođenje, pohranjivanje, odašiljanje te čuvanje pisanih dokumenata, listina, povelja, darovnica, kao i na proizvodnju rukopisnih kodeksa mahom religijskog te sporadično i svjetovnog sadržaja, na epigrafiku, lapidarne spomenike, kovanice, nakit, oružje - riječju, na raznolike artefakte koji bi se u kasnijoj podjeli na različite tipove baštinskih ustanova i zvanično rasporedili unutar, u modernom smislu govoreći, arhivske, bibliotečke i muzejske zbirke. Jasno je, ove prve oblike proizvodnje i sabiranja predmeta te artefakata koje danas prepoznajemo kao dio baštinske građe valja posmatrati unutar konteksta u kojem su nastali, s jasnom, prije svega pragmatskom te dokaznom dimenzijom (što se posebno odnosi na srednjovjekovne administrativne spise), ali se, s obzirom na običaje života srednjovjekovne bosanske vlastele, ne može isključiti ni estetska, dekorativna, uopće duhovna vrijednost pohranjenih predmeta, pogotovo ako se ima u vidu ondašnji paralelizam u običajima života bosanskih i humskih podneblja s podnebljima zapadnih srednjovjekovnih državnih tvorevina.

Dakle, bosanski srednji vijek nije institucionalizirao niti jedan tip baštinske ustanove govoreći u strogo formalnom smislu, ali su vlastelinske i dvorske prakse proizvodnje, sabiranja te čuvanja predmeta koje danas prepoznajemo kao baštinske zasigurno postojale, čemu bi u prilog govorila i nekoć bogata proizvodnja raznolikih predmeta da, stjecajem burnih ratnih okolnosti te nestabilnosti podneblja, mnogi nisu otuđeni, raseljeni te uništeni. U kasnijem, osmanskom periodu najprije će se odigrati institucionalizacija biblioteka, dok su pred sami kraj osmanskog perioda u Bosni evidentne težnje za institucionalizacijom muzejske djelatnosti, a posredno $\mathrm{i}$ arhivske kroz djelatnost te modernizaciju poslovanja Vilajetskog arhiva, što će, u slučaju muzejske djelatnosti u austrougarskom periodu, rezultirati institucionalizacijom muzejske djelatnosti, dok se ideja osnivanja Zemaljskog arhiva ipak neće realizirati niti unutar ozbiljnije planiranog austrougarskog okvira.

Bez obzira na različite periode formalne institucionalizacije ustanova koje danas diferenciramo u biblioteke, arhive, muzeje i ostale srodne baštinske i/ ili informacijske ustanove - što su njihove savremene odrednice $-u$ Bosni i Hercegovini, i prije formalne institucionalizacije baštinskih ustanova, postoji baštinska djelatnost, jasno je, drugačijih zadataka, ciljeva i konačnih ishoda u odnosu na onu danas, ali i na tragu sinkretizma, dakle cjelovitosti, nepodijeljenosti bibliotečkih, arhivskih i muzejskih praksi. Primjere sinkretizma susrećemo i u najstarijim svjetskim baštinskim ustanovama, tipa hramova te riznica oplemenjenih čuvanjem vjerskih i svjetovnih vrijednosti u starovjekovnim kulturama Srednjeg Istoka, uključujući, recimo, i čuvenu asirsku Asurbanipalovu biblioteku iz 7. st. pr. n. e. te kasniju helenističku Aleksandrijsku biblioteku iz 4/3. st. pr. n. e., jasno izdiferenciranu u pravcu mjesta proizvodnje i čuvanja znanja, pa nadalje - sve do humanističkih te novovjekovnih praksi čuvanja vrijednosti prirodnog i "umjetničkog" porijekla unutar evropskih tzv. kabineta rijetkosti (usp. Vešler 1998) - nastalih i kao rezultat potrebe pokazivanja, odnosno reprezentacije neobičnih prirodnih vrsta i predmeta dopremljenih s prvih kolonijalnih osvajanja, kao mode ondašnjeg evropskog visokog društva. U ovim i sličnim primjerima jasna podjela predmeta na tipove zbirki još uvijek ne postoji te se, u skladu s ondašnjim sinkretizmom, baštine predmeti i vrste različite rijetkosti i vrijednosti.

Pismenost, proizvodnja pisane građe te sabiranje predmeta zasigurno su u srednjovjekovnoj Bosni njegovani u vladarskim i plemićkim dvorovima, ali 
i u samostanima, čiji se prvi tragovi spominju u 14. stoljeću, s njima u početku i omanje kolekcije knjiga - ne i izdvojene biblioteke, što je praksa koja će se postupno razvijati, posebno unutar osmanskog perioda u Bosni. Jačanjem prvih samostanskih kolekcija knjiga - koje se uz biblioteke islamske vjerske zajednice osmanskog perioda u Bosni opravdano smatraju jednima od ishodišta baštinske djelatnosti ovih podneblja - započinje duga historija institucionalnog djelovanja baštinskih ustanova u Bosni i Hercegovini.

I u manastirima postoji proizvodnja knjiga, mahom liturgijskog karaktera, koja će se značajnije razvijati kroz osmanski period naovamo, dok će istovremeno u burnoj historijskoj te nerijetko otvorenoj ideološkoj ulozi manastira naspram ne samo osmanskih već i kasnijih austrougarskih vlasti nerijetko ne samo stradavati nego i rezultirati uništenjem rukopisnog blaga. Kako historija franjevačkih samostana u Bosni seže još u vrijeme bosanske samostalnosti, samostani su se brižljivije starali o knjizi te o pisanoj građi uopće, iako čak i ovdje sve do 19. st. nema jasnih, ujednačenih pravila organizacije građe $i$ fondova.

Tradicija čuvanja i zaštite građe koju danas svrstavamo u arhivsku, bibliotečku i muzejsku građu u Bosni i Hercegovini iznimno je duga, istovremena ondašnjim širim evropskim okvirima, manjeg opsega, ali neupitne vrijednosti, jednakih ciljeva, principa očuvanja i funkcionalnosti, riječju, jednakog značaja i uloge, posebice u lokalnom, matičnom kontekstu. Istina, mehanizmi skrbi o dokumentima u srednjovjekovnoj Bosni i Humu, što u modernom smislu pripada djelatnosti arhivskih ustanova, ne mogu se potvrditi faktografijom kakva se susreće u slučaju, recimo, susjedne Dalmacije i njezinog Državnog arhiva u Dubrovniku - ustanove nemjerljivo važne i u izučavanju bosanske srednjovjekovne samostalnosti (usp. Kurtović 2019) - u kojem se spisi organizirano čuvaju još od 1278. godine, što je vidljivo na osnovi sačuvanih gradskih statuta, $s$ unesenim jasnim odredbama o ovom pitanju (Rodinis 2004, 4-5). Iako je u Bosni i Hercegovini sačuvano svega nekoliko povelja iz srednjeg vijeka, koje su danas pohranjene u Arhivu Bosne i Hercegovine te u Zemaljskom muzeju Bosne i Hercegovine, jer se većina građe o srednjovjekovnoj povijesti Bosne i Huma nalazi izvan granica zemlje, ipak se iz istraživanja Ante Babića, Pavla Anđelića, Gregora Čremošnika te i kasnijih autora otkrivaju specifičnosti kancelarija bosanskih vladara, tipa natpisa na narodnom, a ne samo na latinskom jeziku, odabira njemačkog umjesto italijanskog pergamenta, konzistentnosti pisarevog potpisa, simbolike crvene boje pečatnog voska kao isključivo vladarske $\mathrm{i} \mathrm{dr}^{2}$ Pre-

2 O srednjovjekovnim kancelarijama u Bosni više u: Babić 1933; Anđelić 1970; Čremošnik 1976; 1948-1951. ma dostupnim preživjelim tragovima prošlosti, uključujući i popis depozita porodice Hranići (Kosača) pohranjen u Dubrovniku, postojalo je organizirano čuvanje spisa, knjiga i ostalih dragocjenosti, nerijetko i skupno, i to na dvorovima istaknutih velikaša, iako su za srednjovjekovni bosanski i humski okvir čuvanja baštinske građe iznimno važni i samostani, koji će tradiciju pohrane i čuvanja nastaviti te razviti i u osmanskom periodu, i danas bivajući mjesta pohrane važnih osmanskih i drugih dokumenata, kodeksa, inkunabula i drugih vrijednosti.

Imajući u vidu dugu tradiciju čuvanja pisane i druge građe u Bosni i Hercegovini, uključujući i spise administracije, u prvi mah takvo se što odnosi isključivo na čuvanje građe dok je kod svojih stvaratelja, što je, izuzevši ovdje ulogu samostana, prije svega onog u Kraljevoj Sutjesci, Fojnici i Kreševu, kao i Gazi Husrev-begove biblioteke i kasnijeg Zemaljskog muzeja Bosne i Hercegovine, rezultiralo gubitkom mnogih vrijednih akata administracije i drugog pisanog naslijeđa uslijed nepostojanja specijaliziranih arhivskih ustanova, ali uz spašavajuću, nezamjenjivu ulogu nabrojanih, u suštini svoga poslanstva i bavljenja baštinom, višefunkcionalnih ustanova. Iako samostani, Gazi Husrev-begova biblioteka i Zemaljski muzej Bosne i Hercegovine nisu namjenski bili usmjereni k očuvanju spisa, posebno ne onoga što je arhivska građa danas, zasigurno su bili zaslužni za očuvanje dijela arhivske građe od koje se i do danas neka s pijetetom čuva u Bosni i Hercegovini. Upravo primjeri ovih institucija očigledni su pokazatelji konvergiranih praksi baštinskih ustanova i u Bosni i Hercegovini, rezultat čega jesu i današnji paralelizmi i sinkretizmi u njihovoj savremenoj ulozi.

Pojava svjetovnih riznica, uz one unutar crkava, samostana i manastira u Bosni i Humu, istovremena je srednjovjekovnim evropskim riznicama, pa iako je period prije institucionalizacije muzeja u Bosni i Hercegovini još uvijek nedovoljno istražen, srednjovjekovni vladajući sloj uz rukopise i spise zasigurno pohranuje i predmete rijetkosti, kao, ponajprije, predmete ekonomske i pragmatične vrijednosti, potom predmete shvaćene kao dokaze trajanja pojedinih loza i porodica, kao svjedočanstva događaja u kojima su učestvovali i sl. Kratak, ali vrijedan historijski pregled novijeg datuma o razvoju muzejske djelatnosti u Bosni i Hercegovini autorice Alme Leke u knjizi Muzeji, zbirke i galerije u Bosni i Hercegovini, govoreći o počecima sabiranja u Bosni i Hercegovini te o svjetovnim riznicama, podsjeća na ranija istraživanja o srednjovjekovnim riznicama bosanske vlastele, čiji inventari nisu u cijelosti poznati, ali za koje postoje oporuke i popisi depozita na osnovu kojih su moguće rekonstrukcije sabiranja i čuvanja ne samo onoga što bismo u današnjoj terminologiji ocijenili kao bibliotečku 
ili arhivsku već, u ovom konkretnom slučaju, i kao muzejsku građu, tipa izrađevina od metala, ukrašenih biserom i dragim kamenjem, nakita, posuđa, insignija, kruna, krstova, pojaseva, novca i dr. (usp. Leka 2017, 17-30)

Stoga, prakse sabiranja raznolikih predmeta koji se danas diferenciraju unutar tri istaknute baštinske ustanove zabilježene su još za vrijeme trajanja bosanske srednjovjekovne samostalnosti - a barem mali dio artefakata iz ovog vremena opstao je sve do danas, istina, uglavnom izvan Bosne i Hercegovine, dijelom i kao nesistematizirana arhivska građa pohranjena na području današnje Republike Turske - pojavljujući se, prije svega, u vlastelinskim dvorovima, a dijelom i u vjerskim ustanovama, što razvoj baštinske djelatnosti u Bosni i Hercegovini smješta daleko u prošlost, $\mathrm{u}$ korak $\mathrm{s}$ istovremenim evropskim kolekcionarskim praksama te, što posebno valja naglasiti, $\mathrm{s}$ funkcijom $\mathrm{i}$ ishodima koji su u temelju imali pragmatske namjene, ali koji su, kao i u ondašnjoj Evropi, gdjegod prelazili ekonomske i dokazno-pravne zadatosti, ulazeći u funkciju reprezentacije, uključujući i zanatsko-umjetničku vrijednost, što su temelji kasnijeg razvoja baštinskih ustanova, posebice muzejske djelatnosti.

\section{Osmanska kultura u Bosni i Hercegovini: doba prevlasti biblioteka}

Mnoge kulturne tekovine vezane uz ono što danas određujemo kao baštinske ustanove uspostavljene su još u osmanskoj Bosni, integrirajući se ulaskom ovih podneblja u sastav Osmanskog carstva te u već izraslu, višestoljetnu islamsko-orijentalnu pismovnu i kulturnu tradiciju, ali i istovremeno ne zatirući te ipak kontinuirajući, istina bitno drugačije, postojeće pismovne i druge kulturne prakse srednjovjekovne Bosne. Nova religija, kultura, jezici i pismo, riječju, novi kulturni i duhovni ambijent presudno će utjecati na uspostavu te na ranu institucionalizaciju baštinskih ustanova, od kojih neke, poput Gazi Husrev-begove biblioteke - kao jedne od najstarijih evropskih biblioteka uopće - postoje i danas.

Prve ozbiljnije kolekcije knjiga na ovim prostorima vezane su uz vjerske, odnosno vjersko-obrazovne ustanove, uz džamije, mektebe, medrese i tekije te uz crkve, samostane i manastire, što je praksa koja će se, uz privatno sabiranje knjiga, nastaviti stoljećima, sve do, recimo, devetnaestostoljetnih biblioteka kulturno-prosvjetnih društava, državnih škola, te još kasnijih radničkih, specijalnih i javnih biblioteka 20. stoljeća, ali i preživjevši uz matične vjerskoobrazovne ustanove sve do danas.

Dugi osmanski period u Bosni i Hercegovini vrijeme je oblikovanja i izrastanja prvih biblioteka u Bosni i Hercegovini, kao uopće prvih jasno izdiferenciranih te prepoznatljivih baštinskih ustano- va ovog podneblja, o čemu posredno saznajemo iz preživjelih vakufnama, umnogome na osnovu vlasničkih i vakufskih bilješki s margina sačuvanih islamskih rukopisa te iz postojeće, relativno obimne literature, a koja pokazuje da se o razvoju biblioteka u osmanskom periodu u Bosni i Hercegovini pisalo mahom disperzirano, iz perspektive historije, kulturne historije, orijentalistike, bibliotekarstva te u vezi s posebnim, izdvojenim temama ili fenomenima, a dosad vjerovatno najintegriranije u magistarskom radu Osmana Lavića Biblioteke u Bosni u periodu osmanske vladavine iz 2013. godine. Navedena studija, osim metodološkog doprinosa rada na stvarnim rukopisima, otkrivanja vakufskih bilješki i dosad nepoznatih detalja te novog povezivanja i interpretacije ranije poznatih činjenica, vrijedna je i u tome što na jednom mjestu, dakle cjelovito, sabire te upućuje na dosadašnja istraživanja biblioteka u Bosni u osmanskom periodu, ne zaboravljajući na sudbinu te na kontinuiranje kolekcija knjiga katoličke i pravoslavne provenijencije, a koje osmanska kultura zatiče u Bosni, te koje za vrijeme osmanske uprave također zadobivaju jasnije konture unutar samostana i manastira u Bosni i Hercegovini.

Iako se opravdano pretpostavlja da je do danas sačuvan samo neznatan dio rukopisnog blaga donesenog ili proizvedenog / prepisanog te čuvanog na području Bosne i Hercegovine za vrijeme osmanske uprave, polazeći od činjenice da je knjiga punila rafe, ormare i druge prostore džamija, mekteba, tekija, a posebice medresa, za koje se vjeruje da ih je u osmanskoj Bosni djelovalo najmanje stotinu, gotovo sva veća mjesta imala su biblioteke te, što posebno valja naglasiti, u izraslijim sredinama ne samo medresanske već i one javne, samostalne, izdvojene ustanove, što je praksa koju ranije ne zatičemo te s kojom započinje historija samostalnih baštinskih ustanova u Bosni i Hercegovini.

Međutim, uspostava mreže medresanskih, džamijskih, tekijskih i drugih biblioteka u okviru osmanske gradske kulture novi je kulturni obrazac za ova podneblja, takav s kojim započinje rana institucionalizacija baštinskih ustanova u Bosni i Hercegovini, što je perspektiva koja se, u bavljenju pojedinačnim bibliotekama, posebice onom najvažnijom Gazi Husrev-begovom bibliotekom - nerijetko nedovoljno naglašavala, tim prije što ni do danas nije objavljena cjelovita, zajednička studija o razvoju baštinskih ustanova u Bosni i Hercegovini u komparativnoj perspektivi razmatranja triju najizraslijih tipova baštinskih ustanova danas - biblioteka, arhiva i muzeja. Takva bi studija zasigurno morala krenuti upravo od uloge islamskih biblioteka u Bosni i Hercegovini u procesima rane institucionalizacije baštinskih ustanova ovih podneblja, uključujući, naravno, i ranije kolekcije knjiga vezane uz samostane 
i manastire, a koji svoje jasnije institucionalne obrise zadobivaju tek u osmanskom periodu.

Razumljivo, najveća pažnja ranijih istraživača, mahom historičara, kulturnih historičara, bibliotekara te orijentalista, posvećivana je Gazi Husrev-begovoj biblioteci, i to zbog njezinog nemjerljivog značaja, kako same po sebi, s obzirom na trenutak i značaj njezine institucionalizacije, tako i u odnosu prema drugim islamskim bibliotekama u Bosni i Hercegovini, za koje je nerijetko imala presudnu ulogu spašavanja ugroženih i zanemarenih rukopisnih fondova i ostale građe - skrbiteljsku ulogu koju časno nosi te zadržava sve do danas. Vrijedan prilog rasvjetljavanju višestoljetne uloge Gazi Husrev-begove biblioteke u razvoju ne samo bošnjačke već cjelokupne kulture u Bosni i Hercegovini pronalazi se i u recentnoj jubilarnoj monografiji Gazi Husrevbegova biblioteka: 480 godina postojanja, objavljenoj 2017. godine.

Gazi Husrev-begova biblioteka od svojih početaka, a posebice danas, primjer je sinkretizma baštinskih djelatnosti te baštinske ustanove kao takve, obuhvatajući svojom djelatnošću arhivsku, bibliotečku, muzejsku, konzervatorsko-restauratorsku, riječju, cjelokupnu baštinsku djelatnost, te aktivno sudjelujući u razvoju svih triju istaknutih baštinskih djelatnosti u Bosni i Hercegovini danas, uz status te prepoznatljivost i u širim evropskim te svjetskim okvirima.

Posljednje decenije osmanske uprave u Bosni, a u sklopu opće modernizacije Osmanskog carstva te podjele države na vilajete, vrijeme su administrativnih promjena te unapređivanja praksi upravljanja spisima, najprije u matici Carstva, a posljedično i na njegovoj krajnjoj periferiji, nerijetko po uzoru na zapadnjačke prakse, što će se odraziti i na poslovanje ovdašnjeg arhiva Bosanskog vilajeta. Kako administrativna uprava više nije bila strogo centralizirana, pri vilajetskog upravi osnivana su nadleštva za čuvanje spisa. Ipak, sve te promjene, iako prepoznate te vrednovane i u ovdašnjoj literaturi, još uvijek ne dovode do formalne institucionalizacije te do izdvajanja arhiva u zasebne ustanove, kao što je to slučaj s bibliotekama u osmanskom periodu.

Kolekcionarske prakse zasigurno ne zamiru niti unutar dugog, razuđenog perioda osmanske uprave u Bosni, pojavljujući se i dalje kao riznice te prostori za smještaj dragocjenih predmeta unutar vjerskih i vjersko-prosvjetnih ustanova, tipa džamija, tekija, samostana, manastira te samostalnih biblioteka, recimo Gazi Husrev-begove biblioteke, ali i bez dovršetka procesa formalne institucionalizacije ustanove tipa muzeja, i pored jasnih prijedloga ovog tipa pred kraj osmanske uprave. Usto, osobito među Bošnjacima tokom 17. i 18. stoljeća, u okviru urbanog gradskog života pojavljuju se porodične kolekcije vrijednih predmeta $\mathrm{s}$ jasnom funkcijom reprezentacije, istovremene s ondašnjim istočnjač- kim, ali i zapadnjačkim kolekcionarskim praksama (usp. Bejtić 1974, 147-167). Početkom 19. st. u kući hadži Ahmed-bega u Trebinju spominje se soba za starine, s predmetima čuvanim u seharama, gdje su bile smještene povelje i pisma, odijela, oružje i sl. (Defter Darović 1897, 193-226).

Zalaganje za osnivanje muzejskog društva te za institucionalizirano očuvanje starina i narodnog blaga, pod vodstvom fra Ivana Franje Jukića, odigrava se upravo u posljednjim, nestabilnim desetljećima osmanske uprave u Bosni i Hercegovini, ali će se stvarna realizacija ovih ideja, s osnivanjem Muzejskog društva te Zemaljskog muzeja Bosne i Hercegovine, ipak odigrati u narednim desetljećima $u$ okviru austrougarske uprave u Bosni i Hercegovini.

\section{Muzej na sceni i baštinski sinkretizam zapadnoevropskog kulturnocivilizacijskog kruga}

Iako će se s austrougarskim periodom u Bosni i Hercegovini pojaviti mnoge tekovine ondašnje zapadnjačke kulture, dio tog utjecaja vidljiv je i djelatan već i ranije, u modernizaciji Osmanskog carstva posljednjih decenija 19. stoljeća, što će za Bosnu i Hercegovinu imati direktne učinke i u onome što određujemo kao knjižnu kulturu, posebno s obzirom na otvaranje Vilajetske štamparije u Sarajevu, a kratkotrajno i u Hercegovini. Ovakvo što rezultiralo je porastom publikacija na bosanskom jeziku te uopće snažnom proizvodnjom prije svega periodičnih, a potom i ostalih tipova publikacija. Posljedica razvoja štamparske i novinske djelatnosti jeste i postepena pojava knjižarske djelatnosti - koja će buknuti upravo u narednom, austrougarskom periodu - jačajući fondove ne samo postojećih bibliotečkih ustanova već $\mathrm{i}$ onih posve novih, dotad nepoznatih, tipa državnih biblioteka, biblioteka državnih škola, biblioteka radničkih društava i slično, dok istovremeno jača i privatno kolekcioniranje knjiga, bilježeći veliki uspon privatnih biblioteka među svim konfesijama. Nerijetko su privatne biblioteke uglednika, posebno od ovog perioda naovamo, jednako kao i novoosnovane knjižare, knjigu davale na posudbu, funkcionirajući na razmeđi privatnog i javnog te popunjavajući, na izvjestan način, očiglednu prazninu koja je nastajala gašenjem istaknutih javnih ili medresanskih biblioteka osmanskog perioda, koje se u uvjetima nepovoljnog odnosa prema instituciji vakufa u austrougarskom periodu uopće ili gase, ili, u najboljem slučaju, slijevaju u Gazi Husrev-begovu biblioteku.

Slijevanje brojnih, ne samo privatnih već i medresanskih, javnih i ostalih vakufskih biblioteka u Gazi Husrev-begovu biblioteku proces je doveden do vrhunca s novim odnosom prema vakufskoj imovini $\mathrm{u}$ austrougarskom periodu u Bosni i Hercegovini, pri čemu se i biblioteke iz državnog ili javnog do- 
bra - iz predmeta općeg javnog interesa - pomjeraju u strogu konfesionalnu sferu - izmještajući se iz svog višestoljetnog okvira te dolazeći na sami rub egzistencije, što je, recimo, bio i put gašenja Osman Sehdijine biblioteke, ali i mnogih drugih manje poznatih biblioteka. Uloga Gazi Husrev-begove biblioteke u spašavanju rukopisa i fondova koji su ovim prilikama ostajali "bez krova nad glavom" historijska je i takva da na istom poslanju ostaje sve do danas. Tome treba pridružiti i kolekcioniranje te spašavanje arhivske građe i kulturnih artefakata, dakle - arhivske i muzejske građe, opet potvrđujući temeljnu hipotezu ove studije o sinkretičkim odnosima baštinskih ustanova u Bosni i Hercegovini, od njihovih ranih početaka, pa sve do danas.

Uporedo s gašenjem mnogih vakufskih biblioteka, gdjegod slabljenjem utjecaja franjevačkih, ali i jačanja biblioteka dijecezanske redovne crkvene hijerarhije, traje i proces uspostave novih tipova biblioteka te nove mreže biblioteka u Bosni i Hercegovini pa, konačno, i onih baštinskih ustanova koje do ovog perioda nemaju svoju formalnu institucionalizaciju, kakva je, recimo, muzej. U austrougarskom periodu, u više ili manje pogodnim uvjetima, nastavljaju istrajavati biblioteke vjerskih zajednica, islamske, katoličke, pravoslavne i jevrejske, ali i biblioteke konfesionalnih škola te čitaonice i biblioteke uz društva.

Uz biblioteke državnih ureda, radničkih udruženja te uz onu krovnu, najvažniju, najistaknutiju Biblioteku Zemaljskog muzeja zaokružuje se dotad najkompleksnija slika mreže biblioteka te srodnih ustanova u Bosni i Hercegovini, kao početak vremena od kojeg se fondovi i građa koju danas ocjenjujemo kao baštinsku građu počinju prikupljati, čuvati i interpretirati na naučnoj osnovi, u ustanovama naučnog predznaka te naučnog pristupa pohranjenoj građi.

Novo vrijeme za baštinske ustanove u Bosni i Hercegovini zasigurno otvara uspostava Zemaljskog muzeja Bosne i Hercegovine iz 1888. godine, a nakon višegodišnjih priprema za otvaranje kompleksne ustanove kakva se prvi put pojavljuje u Bosni i Hercegovini, koje su započete još 1884 . godine, mahom pod pritiskom lokalnih intelektualaca ozlojeđenih raznošenjem arheološkog blaga, umjetnina i ostalih dragocjenosti iz Bosne i Hercegovine, što se posebno intenziviralo naučnim "otkrivanjem" Bosne i Hercegovine u austrougarskom periodu, a na što je još posljednjih decenija osmanske uprave upozoravao i fra Ivan Franjo Jukić, insistirajući na osnivanju društva Kolo bosansko te na zaštiti starina i tradicije - što je bila i okosnica pojave te izdavanja prvog bosanskohercegovačkog časopisa pod nazivom Bosanski prijatelj počev od 1850. godine. Ulogu potpredsjednika Privremenog odbora Muzejskog društva iz 1884. obavljao je Mehmedbeg Kapetanović Ljubušak, za predsjednika je biran Kosta Hörmann, a za sekretara Julije Makanec.
Privremeni odbor Muzejskog društva pripremio je uvjete za konstituiranje Muzejskog društva u Bosni i Hercegovini iz 1885. godine, kao prvog ovdašnjeg muzejskog društva uopće, $s$ finalnim ciljem osnivanja prve muzejske ustanove u Bosni i Hercegovini.

Sa Zemaljskim muzejem Bosne i Hercegovine već razvijene evropske bibliotečke, arhivske i muzejske prakse pojavljuju se i u Bosni i Hercegovini, zatičući već izvjesne baštinske tradicije, ali ih očito modernizirajući te približavajući novom odnosu prema baštinskoj građi, začinjući naučnu djelatnost te naučni odnos zapadnog tipa prema baštinskoj građi u Bosni i Hercegovini. Ovakvo što, posebno ako se ima u vidu načelno afirmirajući odnos nove vlasti prema zatečenoj građi iz osmanskog perioda, na kojoj je, recimo, u Zemaljskom muzeju u svojstvu saradnika radilo i nekoliko istaknutijih predstavnika ondašnje bošnjačke intelektualne elite, poput Sejfudina Kemure, Safvet-bega Bašagića, Fehima Spahe, Rize Muderizovića te brojnih svršenika tadašnje Šerijatske sudačke škole u Sarajevu, pojavu Zemaljskog muzeja Bosne i Hercegovine, kao baštinske ustanove sinkretskog tipa - do te mjere da je kasnije iznjedrila i niz poluzasebnih ili zasebnih baštinskih ustanova, poput Instituta za istraživanje Balkana, Orijentalnog instituta u Sarajevu te Umjetničke galerije Bosne i Hercegovine, bivajući svojim fondovima nukleus izgradnje niza važnih baštinskih ustanova - smješta u prijeloman trenutak razvoja baštinskih ustanova u Bosni i Hercegovini, takav od kojeg odnos prema svim tipovima baštinske građe postaje naučan, transparentan, publikovan te vidljiv široj javnosti.

Isti odnos prema sačuvanoj arhivskoj građi u Bosni i Hercegovini, do ovog vremena mahom pohranjenoj u samostanima, Gazi Husrev-begovoj biblioteci te $\mathrm{u}$ Zemaljskom muzeju Bosne i Hercegovine, koji je od Zemaljske vlade preuzeo nekadašnji Vilajetski arhiv, iako neće rezultirati osnivanjem arhiva kao zasebne ustanove u ovom periodu - i pored ozbiljnih inicijativa u ovom pravcu iz 1909. i 1914. - začetak je novog, naučnog odnosa prema pohranjenim spisima, koji više nisu samo u pragmatskoj već i u funkciji naučne interpretacije, a objavljivanjem u Glasniku Zemaljskog muzeja postaju prvorazredni izvori za proučavanje bosanskohercegovačke naučne, kulturne i umjetničke prošlosti.

\section{U iščekivanju arhiva: vrijeme nedovršenosti mre- že baštinskih ustanova u Bosni i Hercegovini}

Razdoblje između dva svjetska rata vrijeme je kontinuiranja većine ranije uspostavljenih baštinskih ustanova u Bosni i Hercegovini te jednako tako i vrijeme bez očiglednijeg razvoja ovog tipa ustanova, takvog koji bi promijenio dotadašnje razvojne sheme, ali, ipak, uz povremenu, sporadičnu pojavu poneke nove baštinske ustanove, tipa Muzeja Vr- 
baske banovine u Banjoj Luci iz 1930. godine, što će i za muzejsku djelatnost u Bosni i Hercegovini, uz Zemaljski muzej, ostati uglavnom osamljen primjer, sve do svršetka Drugog svjetskog rata te do uspostave modernih muzejskih ustanova u zemlji.

Konfesionalne, pa tako i medresanske, kao i druge školske biblioteke u ovom vremenu trpe oskudicu te nedostatak sredstava za rad, što se odražava na cjelokupan školski bibliotečki sistem, iako uvjeti rada nisu zadovoljavajući niti za ostale tipove biblioteka u uspostavljenoj novoj zajedničkoj državi. Za Gazi Husrev-begovu biblioteku u Sarajevu, kao što je već spomenuto, period između dva svjetska rata vrijeme je slijevanja te jedinstvenog okupljanja samostalnih, medresanskih i privatnih zbirki islamskih biblioteka iz ranijeg vremena, ali i vrijeme naučne valorizacije pristiglih fondova, naučne orijentacije Biblioteke, vrijeme uspostave važnih domaćih i međunarodnih kontakata, sve to najprije zahvaljujući radu dugogodišnjih bibliotekara ove biblioteke Mehmeda Handžića, nakon toga Mahmuda Traljića, ali i drugih. Između dva svjetska rata, kraće ili dugotrajnije, nastavlja se i rad ranije uspostavljenih čitaonica, uključujući i one muslimanske - kiraethane, istina sada pod nadzorom Ministarstva prosvjete, dakle novonastale države i njezinog državnog aparata, te shodno nastojanjima da se ostvari jugoslavensko jedinstvo, nerijetko mijenjajući nazive u "jugoslovenska", "građanska", "narodna", a najčešće u "narodna knjižnica i čitaonica" (usp. Bašović 1986, 29-38). Ovo je jednako tako i vrijeme osnivanja novih čitaonica, reorganizacije ili rada u skladu s novim pravilima ranijih čitaonica, ali i vrijeme gašenja nekih istaknutih čitaonica, poput Muslimanske kiraethane na Bentbaši, s 1929. godinom kao godinom njezinog okončanja.

Za bivšu zajedničku državu, vrijeme između dva svjetska rata vrijeme je nasljeđivanja nekoliko ranijih arhiva koji su već postojali do kraja Prvog svjetskog rata, poput onih u Beogradu, Ljubljani, Dubrovniku, Zadru i Zagrebu, dok je u vremenu između dva svjetska rata osnovano i nekoliko novih arhiva, u Novom Sadu, Skoplju, Mariboru, Varaždinu, Rijeci te pri Muzeju Cetinja u Crnoj Gori. No Andrej Rodinis, valorizirajući period od 1918. do 1945. godine u spomenutoj magistarskoj radnji $A r$ hivska služba Bosne i Hercegovine: povijesni razvoj $i$ perspektive iz 2004. godine, napominje da se o mnogima od spomenutih arhiva u ovom periodu ne može govoriti kao o organiziranim niti uopće samostalnim ustanovama, pogotovo ne kao o modernim arhivskim ustanovama kakve i Bosna i Hercegovina dobija nakon Drugog svjetskog rata. Ipak, područje Bosne i Hercegovine jedino je u sklopu zajedničke države ostalo bez nadležnog arhiva, a, prema Andreju Rodinisu, razlozi za takvo što su i "politikantska manipuliranja i zloupotreba arhivskog gradiva"
(Rodinis 2004, 16), pa pitanje restitucije, otkupa ukradene arhivske građe, njezino otuđenje, razbijanje cjeline fondova te drugi oblici uništavanja, raznošenja te siromašenja nastale arhivske građe ostaju ključne odlike ovog perioda kada je arhivski segment djelovanja baštinskih ustanova u pitanju.

Ipak, i pored odsustva organizirane arhivske službe i pripadajućih ustanova u Bosni i Hercegovini u ovom periodu, valja spomenuti i predloženo osnivanje arhiva u Sarajevu, koje nije realizirano, a bilo je predviđeno okvirima Projekta Zakona o državnim arhivima i registraturama Kraljevine Jugoslavije između 1931. i 1934. godine, kao i neuspjeli pokušaj vezan uz Nacrt uredbe o banovinskim arhivima autora Josipa Nagija, s jednim od četiri banovinska arhiva koji je trebao imati središte u Travniku. Pored spomenutih neuspjelih pokušaja, do Drugog svjetskog rata doneseno je nekoliko propisa iz uredskog poslovanja, koji su koliko-toliko umanjili nered te štete načinjene u upravljanju spisima u ovom periodu, a o čemu su arhivisti izvještavali i nekoliko desetljeća kasnije (usp. Rodinis 2004, 15-18).

Stvarne, suštinske promjene za bosanskohercegovačke baštinske ustanove, a posebno i za razvoj baštinskih službi te profesija u pravcu njihove formalne te moderne institucionalizacije, nastupaju u periodu nakon Drugog svjetskog rata, kreirajući okvire unutar kojih ove ustanove više-manje djeluju i danas.

\section{Na putu ka modernim baštinskim ustanovama u Bosni i Hercegovini}

Niz vrijednih izdanja, ne samo monografskih već $i$ periodičnih publikacija, ukazuje na gotovo istovremenost završetka niza procesa unutar bibliotečke, arhivske i muzejske djelatnosti pripremanih razvijenom baštinskom tradicijom u Bosni i Hercegovini stoljećima unatrag, a da bi procesi kulminirali formalnom, modernom institucionalizacijom baštinskih ustanova - arhiva, biblioteka, muzeja, galerija, zbirki i drugih srodnih ustanova - u prvim poslijeratnim godinama druge polovine 20. st. Vrijeme je to od kojeg bilježimo nastanak modernih baštinskih ustanova, udruženo s razvojem profesije, pripadajućeg zakonodavstva, akademskog obrazovanja za barem jednu od navedenih baštinskih profesija - i to bibliotekarstva - riječju, procesi evidentno zakasnjeli u odnosu na šire evropske i svjetske okvire, ali i relativno slični širem južnoslavenskom okviru unutar kojeg će se, recimo, bosanskohercegovačko bibliotekarstvo nerijetko isticati u predvođenju novih obrazovnih i strukovnih praksi, što će se, nažalost, kao status profesije urušiti agresijom na Bosnu i Hercegovinu te jednako teškom i složenom poslijeratnom praksom u novim, nezahvalnim političkim, administrativnim, ekonomskim te uopće društvenim okvirima. 
Od inicijalnog razvoja baštinskih ustanova povezanih s vjerskim zakladama, bibliotekama konfesionalnih zajednica, preko biblioteka kulturno-prosvjetnih društava, školskih, radničkih, specijalnih, pa sve do onih javnih poput Narodne biblioteke NR Bosne i Hercegovine iz 1945. ili Narodne biblioteke "Hasan Kikić", današnje Biblioteke Sarajeva, iz 1947. godine pa nadalje, uspostavlja se mreža modernih bibliotečkih ustanova, u kojima su sada ingerencije jasno podijeljene, ne više prema konfesionalnoj pripadnosti, kao u ranijim stoljećima, već prema specifičnim strukovnim zadacima unutar kojih je, recimo, jasna razlika između centralne bibliotečke ustanove u zemlji koja skrbi o obaveznom primjerku, nacionalnoj bibliografiji, međunarodnoj bibliotečkoj pozajmici, međunarodnoj identifikaciji publikacija i slično, na jednoj, te narodnim, gradskim, javnim bibliotekama s brigom o zavičajnoj građi, lokalitetu te matičnoj lokalnoj zajednici uopće, na drugoj strani.

Kako u već spomenutoj, dosad najcjelovitijoj studiji o postsocijalističkom razvoju bibliotekarstva u Bosni i Hercegovini upućuje i Senad Čeliković, kao i niz drugih autora unutar brojnih periodičnih izdanja, vrijeme od Drugog svjetskog rata pa do 1992. godine najdinamičniji je te najslojevitiji period u ovdašnjem bibliotekarstvu, ne samo zbog činjenice da iz tog vremena potječe moderna mreža biblioteka u Bosni i Hercegovini već i zbog uspostave strukovnih, zakonodavnih i obrazovnih okvira profesije, koje u manjoj ili većoj mjeri nasljeđujemo sve do danas. Vrijeme od 1945. do 1975. godine vrijeme je munjevitog širenja broja biblioteka u zemlji, uz državnu strategiju razumijevanja bibliotečke djelatnosti kao djelatnosti od posebnog društvenog interesa, rezultat čega je uspostavljena mreža narodnih, školskih, visokoškolskih i specijalnih biblioteka s centralnom, Narodnom bibliotekom NR Bosne i Hercegovine, koja 1975. godine proširuje svoju funkciju u pravcu jačanja Univerziteta u Sarajevu, izrastajući u Narodnu i univerzitetsku biblioteku Bosne i Hercegovine, sve do 1995. godine kada postaje Nacionalna i univerzitetska biblioteka Bosne i Hercegovine. Ovaj uspon bosanskohercegovačkog bibliotekarstva nastavlja se i sedamdesetih i osamdesetih godina 20. st. praćenjem međunarodnih standarda u opisu i obradi bibliotečke građe, donošenjem nekolika zakonska propisa važna za uređenje niza strukovnih pitanja, aktivnostima Društva bibliotekara Bosne i Hercegovine još iz 1949. godine, pokretanjem strukovnih glasila Bilten i Bibliotekarstvo, uspostavom srednjoškolskog i visokoškolskog obrazovanja iz oblasti bibliotekarstva, organziranim stručnim obrazovanjem i institucijom stručnih ispita te nizom društveno korisnih akcija u oblasti bibliotekarstva, što su suštinski temelji ne samo institucionalne izgradnje već i temelji izrastanja bibliotečke profesije u Bosni i Hercegovini, kao struke i kao nauke, koji su tim prije važniji, jer rezultate ovih procesa baštinimo sve do danas.

Od osamdesetih godina 20. stoljeća naovamo započela je primjena međunarodnih standarda za bibliografski opis, uvedena je saradnja danas Nacionalne i univerzitetske biblioteke Bosne i Hercegovine s bosanskohercegovačkim izdavačima na poslovima katalogizacije na izvoru (CIP) i dodjele ISBN-a, doneseni su standardi za univerzitetske, specijalne i narodne biblioteke, standardi za prostorije i opremu biblioteka, potom standardi i normativi za bibliotečku djelatnost uopće, dva važna Zakona o bibliotečkoj djelatnosti, jedan iz 1978. te unaprijeđeni iz 1986. godine, a što su sve skupa mahom i osnove donošenja entitetskih zakona i pravilnika kojima se bibliotečka djelatnost regulira u poslijeratnom periodu, dok su neki od ovih dokumenata, u nepostojanju novih zakonskih akata i podataka, iako iz ranije zajedničke države, nastavili važiti sve do danas.

Vrijeme je ovo i osjetne praznine u akademskom školovanju bibliotekara u zemlji, rezultat čega je i uspjela namjera pokretanja studija bibliotekarstva na Filozofskom fakultetu u Sarajevu u ak. 1971/1972, kada je osnovan Odsjek za opštu književnost, scenske umjetnosti i bibliotekarstvo, danas Odsjek za komparativnu književnost i informacijske nauke, i to nakon ranijeg začetka formalnog obrazovanja bibliotekara na Višoj pedagoškoj školi u Sarajevu. U poslijeratnoj Bosni i Hercegovini studij bibliotekarstva pokrenut je ak. 1996/1997. i na Filozofskom fakultetu Univerziteta u Istočnom Sarajevu te u ak. 2005/2006. studij informacijskih nauka na Sveučilištu u Mostaru.

Moderna arhivska služba u Bosni i Hercegovini, kao i u slučaju biblioteka, započinje nakon Drugog svjetskog rata osnivanjem Državnog arhiva NR Bosne i Hercegovine od 12. 12. 1947. godine, što je datum koji se danas obilježava kao Dan arhivâ Bosne i Hercegovine, a pojavu ovog, prvog arhiva prati i skora pojava Arhiva Grada Sarajeva iz naredne, 1948. godine, što svakako arhivsku službu u Bosni i Hercegovini čini jednom od najmlađih u Evropi, pa i u regionu, no, ovakvo što moglo bi proizvesti i pogrešan zaključak da Bosna i Hercegovina nema dugu tradiciju čuvanja arhivalija, što se, ukoliko se vratimo stoljećima unazad, počev od srednjovjekovnih kancelarija bosanskih vladara, preko čuvanja dokumenata u samostanima $\mathrm{i}$ ostalim vjersko-obrazovnim ustanovama, tipa medresanskih biblioteka ili, pak, onih samostalnih kakva je od 1863. Gazi Husrevbegova biblioteka $\mathrm{u}$ osmanskom periodu te posebno $\mathrm{u}$ austrougarskom periodu u okviru Turskog arhiva Zemaljskog muzeja, uspostavlja netačnim - riječju, $\mathrm{i}$ bez formalne institucionalizacije arhiva u Bosni i Hercegovini, druge baštinske ustanove preuzimale su djelimično te stihijski skrb o nastaloj pisanoj gra- 
đi, što je potvrda i trajne, sinkretske veze između baštinskih ustanova međusobno te mogućnosti njihova međusobna nadomještanja u uvjetima nepostojanja jednog od ovih tipova ustanova - riječju reprezentativni primjer njihova konvergiranja.

Ipak, duže odsustvo stvarne arhivske ustanove u modernom smislu riječi za Bosnu i Hercegovinu, uz obilje nepovoljnih uvjeta tipa ratova, smjene državnih i političkih vlasti i drugih pošasti ovog podneblja, rezultirat će nemjerljivim gubicima $\mathrm{u}$ važnim dokumentima, što su posljedice koje će otežati proces institucionalizacije arhivske službe u Bosni i Hercegovini te koje se u radu ovih ustanova osjećaju sve do danas. Stoga je prvi zadatak novoosnovanih arhivskih ustanova bio fizičko spašavanje te zbrinjavanje ugrožene građe, posao nemjerljivo važan, ali i takav da će se služba nerijetko usporiti na ostalim planiranim razvojnim ciljevima, upravo u nastojanju reguliranja te prve, temeljne zadaće novouspostavljenih arhiva. Istina, bez šire arhivske mreže u zemlji nije se moglo govoriti o arhivskom nadzoru nad registraturama te nad ugroženom građom, pa suštinskim početkom arhivske službe u Bosni i Hercegovini, kako na to ukazuje i Andrej Rodinis u spomenutoj publikaciji (2004), valja smatrati tek uspostavu mreže arhivskih ustanova u zemlji, što su procesi koji započinju s periodom od 1953. do kraja 1954. godine, kada je u Bosni i Hercegovini osnovano još pet novih arhiva: 1953. u Banjoj Luci, 1954. u Doboju, Travniku, Tuzli i Mostaru, a 1954. godine osnovano je i Društvo arhivskih radnika Bosne i Hercegovine.

I pored uspostave mreže arhiva, gotovo cijelo prvo desetljeće novonastale ustanove bore se za fizičko spašavanje građe, za društveno prepoznavanje, za nametanje vlastitih, u drugim zemljama već odavno zakonima predviđenih ingerencija, što rezultira izostajanjem zapaženijeg rada na stvarnim strukovnim zadacima, kakvi su stručna obrada građe, izrada obavijesnih pomagala, objavljivanje arhivskih izvora i sl. No, situacija se razvija nabolje donošenjem Zakona o arhivima iz 1962. godine, kao razvojnom osnovom na kojoj će arhivska struka u naredna tri desetljeća, do agresije na Bosnu i Hercegovinu, iako i dalje u ograničenim uvjetima, uspjeti uhvatiti korak s modernom arhivskom službom, nadomješćujući, nerijetko entuzijazmom pojedinaca, propušteno vrijeme te stalno prisutne probleme $u$ finansiranju, prostoru te neadekvatnom obrazovanju arhivističkog kadra u Bosni i Hercegovini, koji tada, pa ni sve dosad, nije dobio svoj akademski, visokoškolski okvir (usp. Rodinis 2004, 136-138).

Složenost profesionalnog djelovanja arhivskih ustanova u Bosni i Hercegovini, kao i u slučaju ostalih baštinskih ustanova, kulminirala je agresijom na Bosnu i Hercegovinu, jer "u brutalnom ratu, u gotovo polovici od ukupnoga registraturnoga gradiva u po- sjedu raznih imatelja nalazilo se nebrojeno arhivsko gradivo, odavno odabrano, ali nepreuzeto $u$ arhive upravo zbog prostornih problema. Istodobno, nepopunjenost potrebnih radnih mjesta u službi dovela je do toga da je ratnim rasulom mnogi arhiv, uslijed ratom izazvanih migracija, tačnije odljeva kadrova, sveden tek na 'vegetiranje'." (Rodinis 2004, 138) Dakle, teška oštećenja arhivske građe desila su se ponajviše u registraturama, upravo zbog već odabrane, a nepreuzete građe, $\mathrm{i}$ to zbog problema s prostorom, o čemu dosad najcjelovitije izvještava Azem Kožar u članku Sudbina registraturne građe u procesu tranzicije (Arhivska praksa, 3, 2000, Tuzla), uz stradanja u Arhivu Hercegovine u Mostaru, u Sarajevu Arhiva BiH, u Tuzli, Bihaću, Travniku, sveukupno oko 70 fondova, odnosno $6,5 \%$ arhivske baštine (Kožar 2001, 186).

Ipak, nemjerljivo najteži gubitak arhivske, ali i bibliotečke građe jeste onaj vezan uz ciljano spaljivanje Orijentalnog instituta u Sarajevu, pri čemu su stradale neprocjenjivo vrijedne zbirke Instituta, i to $M a-$ nuscripta turcica sa 7156 dokumenata od 16. do 19. stoljeća, Zbirka sidžila brojeći 66 sidžila za period od 17. do 19. stoljeća, Vilajetski arhiv s oko 200.000 dokumenata i Zbirka tapija, kao i 5263 rukopisna kodeksa s preko 15.000 naslova te kopije deftera iz istanbulskih arhiva (Ljubović i Gazić 2000).

Shodno novom uređenju države, arhivska djelatnost u Bosni i Hercegovini odvija se na tri razine: državnoj, entitetskoj i kantonalnoj u Federaciji BiH. Takvo rješenje isključuje mogućnost jedinstvenog zakona o arhivskoj službi te nameće situaciju u kojoj svi nivoi vlasti rješavaju pitanja zaštite svoje registraturne i arhivske građe u okviru svojih teritorijalnih okvira svojim zakonskim i podzakonskim aktima. Rezultat je složen zakonodavni okvir za koji je vrijedan izvor informacija Zbirka arhivskih propisa Bosne i Hercegovine 1947-2007 priređivačica Amire Šehović i Džemile Čekić, u zajedničkom izdanju Arhiva Bosne i Hercegovine te Historijskog arhiva Sarajevo iz jubilarne, 60. godišnjice rada u 2007. godini. Zbirkom su obuhvaćeni arhivski propisi od početka organiziranja arhivske službe u Bosni i Hercegovini kao federalnoj jedinici zajedničke države do 1992. godine, kao i arhivski propisi Bosne i Hercegovine kao samostalne države za period od 1992. do 2007, obuhvatajući u svom drugom dijelu niz propisa na nivou Bosne i Hercegovine, Federacije Bosne i Hercegovine, kantona u Federaciji Bosne i Hercegovine, potom na nivou Republike Srpske te Brčko Distrikta Bosne i Hercegovine, ukazujući na složen, ali ipak najreguliraniji zakonodavni okvir kada su baštinske ustanove i njihove službe u Bosni i Hercegovini u pitanju.

Jednako je složena, ali ipak i jasno uspostavljena i mreža arhivskih ustanova u Bosni i Hercegovini danas, pri čemu je Zakonom o arhivskoj građi i Arhivu 
Bosne i Hercegovine iz 2001. godine uređen pravni status Arhiva Bosne i Hercegovine, a iz kojeg je još 1994. godine u samostalnu ustanovu izdvojena Kinoteka Bosne i Hercegovine - baštinska ustanova od nemjerljivog nacionalnog značaja - koja danas, uz još nekolike temeljne baštinske ustanove nacionalnog predznaka, biva krajnje ugrožena nereguliranim pravnim i finansijskim statusom. Na području Federacije Bosne i Hercegovine 1997. započinje s radom Arhiv Federacije kao entitetski arhiv, a ovoj organizacionoj shemi pridružuje se i Arhiv Republike Srpske, Arhiv Brčko Distrikta te sedam kantonalnih arhiva u Federaciji Bosne i Hercegovine, i to u: Sarajevu, Travniku, Mostaru, Tuzli, Šrokom Brijegu, Goraždu i Bihaću, s tim da pojedini kantoni još uvijek nisu regulirali ovu oblast, pa je arhivska građa u nekim područjima Bosne i Hercegovine još uvijek nezaštićena te bez nadležne arhivske ustanove.

Ipak, imajući u vidu obilje navedenih propisa, kojima je arhivska služba u Bosni i Hercegovini uglavnom stavila van snage zakonske odredbe prijeratne zajedničke države te koliko-toliko ujednačila, barem na strukovnom ako ne na organizacijskom nivou, svoju djelatnost, poslijeratno organiziranje, pa i udruživanje u strukovna udruženja na svim nivoima vlasti među arhivistima Bosne i Hercegovine, primjeri su dobre prakse profesionalnog djelovanja i za ostale baštinske zajednice u Bosni i Hercegovini.

Arhivi u Bosni i Hercegovini, osobito najstariji te najistaknutiji među njima, poput Arhiva Bosne i Hercegovine te Historijskog arhiva Sarajevo (dobitnika i Šestoaprilske nagrade Grada Sarajeva u dva navrata), nositelji su i vrijedne izdavačke te izložbene djelatnosti u Bosni i Hercegovini, u okviru koje je objavljena te prezentirana pohranjena arhivska građa, uz izradu analitičkih te sumarnih inventara i drugih obavijesnih pomagala, ali i kapitalni radovi u oblasti historije i kulturne historije Bosne i Hercegovine, čija bi izrada bez građe pohranjene te stručno obrađene u arhivskim ustanovama Bosne i Hercegovine bila neizvodiva.

Svemu valja pridružiti i vrijedna glasila poput nekadašnjeg Glasnika Arhiva i Društva arhivskih radnika Bosne i Hercegovine, s početkom izlaženja u 1961. godini, čiju današnju kontinuaciju predstavlja Glasnik Arhiva i Arhivističkog udruženja Bosne $i$ Hercegovine u izdanju Arhivističkog udruženja Bosne i Hercegovine, koje svojim osnivanjem u 2004. godini nastavlja kontinuitet organiziranja arhivskih djelatnika u Bosni i Hercegovini započet još 1954. osnivanjem Društva arhivskih radnika Bosne i Hercegovine. Od 1998. godine Arhiv Tuzlanskog kantona objavljuje časopis Arhivska praksa, a 2009. godine izašao je prvi broj časopisa Građa Arhiva Bosne i Hercegovine u izdanju Arhiva Bosne i Hercegovine. U Banjoj Luci objavljuje se Glasnik Udruženja arhivskih radnika RS.
Uza sve spomenuto da se naslutiti da se arhivska profesija u Bosni i Hercegovini, i pored krajnje složenih okvira svojeg djelovanja, uspješno nosi s brojnim izazovima, a koji, pored spomenutih, zasigurno obuhvataju i pitanja nepostojanja akademskog okvira za visokoškolsko obrazovanje arhivista te budućnost poslovanja arhiva u elektronskom okruženju, izdvojivši ovdje samo neke od izazovnijih.

I muzejska profesija u Bosni i Hercegovini pokazuje slične razvojne obrasce kao i ostale srodne baštinske profesije - arhivistika i bibliotekarstvo, s dugom djelatnošću u zemlji, ali i s modernom institucionalizacijom te $\mathrm{s}$ uspostavom mreže muzejskih ustanova tek nakon Drugog svjetskog rata, a nakon kojeg su, izuzevši muzejske zbirke vjerskih ustanova, u Bosni i Hercegovini postojala samo dva muzeja, Zemaljski muzej i Državni etnografski muzej Bosanske krajine, raniji Muzej Vrbaske banovine, s obzirom na to da još nekolike inicijative za osnivanje muzeja tokom austrougarskog perioda te perioda između dva svjetska rata nisu ostvarene.

Godine 1982. objavljena je publikacija Muzeji, galerije i zbirke u Bosni i Hercegovini u izdanju Društva muzejskih radnika Bosne i Hercegovine, nakon čega slijedi duga informacijska praznina o ovoj temi, koja je tim prije veća jer su se od osamdesetih godina 20. stoljeća, posebice nakon agresije na Bosnu i Hercegovinu, u muzejskoj mreži Bosne i Hercegovine odigrale stanovite promjene, počev od stradanja zgrada, preimenovanja te uspostave potpuno novih muzeja ili, pak, izgradnje novih zgrada za ranije osnovane muzeje - dakle - nova slika stanja koju uspješno predstavlja publikacija Muzeji, zbirke i galerije u Bosni i Hercegovini autorice Alme Leke iz 2012. godine te posebno njezino drugo, dopunjeno izdanje iz 2017. godine, uz podršku Udruženja ICOM - Nacionalnog komiteta Bosne i Hercegovine (kao današnjeg jedinog okvira strukovne organizacije muzealaca i muzeologa na nivou Bosne i Hercegovine) te povodom obilježavanja 70 godina ICOM-a i 40 godina ICOM-ovog Međunarodnog dana muzeja.

Danas u Bosni i Hercegovini postoji "relativno velika, ali ekstenzivna mreža muzeja" (Leka 2017, 31), čija izgradnja cjelovitije započinje 1945. godine osnivanjem Muzeja narodnog oslobođenja Bosne i Hercegovine, danas Historijskog muzeja Bosne i Hercegovine, te se nastavlja, recimo, osnivanjem Umjetničke galerije Bosne i Hercegovine iz 1946. godine, oformljene oko zbirke umjetničkih djela Zemaljskog muzeja Bosne i Hercegovine, što je otvorilo put zasnivanju sličnih ustanova u ostalim bosanskohercegovačkim gradovima te procesu uspostave mreže muzejskih ustanova u Bosni i Hercegovini.

Nakon agresije na Bosnu i Hercegovinu mnogi muzeji ostali su bez zgrada, dok je novu, namjenski izgrađenu zgradu 2004. godine dobio ranije osnovani 
Muzej grada Zenice (1966), no zamjetno je i osnivanje novih muzeja, ali i privatnih kolekcija, zbirki, galerijskih i srodnih ustanova, od kojih će neke, s ciljem postizanja ili očuvanja statusa muzeja valjati unaprijediti svoje prakse, u skladu s aktuelnom zakonskom regulativom u ovom području. U svakom slučaju, kao primjere dobre prakse i pozitivnih tendencija, a kako to navodi i autorica Leka $(2017,95)$, valja spomenuti Muzej šejha hadži Mesuda Hadžimejlića, Vukeljići (1999), Bošnjački institut - Fondaciju Adila Zulfikarpašića (2001), Galeriju „Enver Krupić“" Bihać (2006), Muzej Alija Izetbegović (2007), Art-kuću sevdaha (2008), Muzej Tešanj (2009), Arheološki muzej „Rimski municipium“ Skelani, Srebrenica (2010), Zavičajni muzej Konjic (2011), Galeriju 11/07/95 (2012), Muzej Gazi Husrev-beg (2012), Spomenički kompleks Tunel D-B / Tunel spasa (2013), Muzej Gazi Husrev-begove biblioteke (2014), Muzej Kakanj (2015), Muzej ratnog djetinjstva (2015), Zavičajni muzej Goražde (2016), Muzej zločina protiv čovječnosti i genocida 1992-1995 (2016), Fondaciju / Legat Ekmečić, Brčko (2017), spomenuvši ovdje samo neke.

Dakle, iako broj muzejskih ustanova očigledno raste od druge polovine 20. stoljeća pa sve do danas posebno ako se ima u vidu da je osamdesetih godina 20. st. u Bosni i Hercegovini bilo tek četrdesetak muzeja, muzejska profesija $\mathrm{s}$ ostalim baštinskim profesijama dijeli slične otežavajuće okolnosti svojeg djelovanja danas, uključujući probleme finansiranja, prostornih, kadrovskih i resursnih ograničenja, svakako i složenosti zakonodavnih okvira, a napose problem nepostojanja akademskog obrazovanja stručnjaka, izuzev onog u slučaju akademskog obrazovanja bibliotekara - što samo po sebi nije dovoljno u situaciji u kojoj, nažalost, postoji zakonom legalizirano dvostruko ulaženje u struku putem neadekvatno razriješene uloge te dometa stručnih ispita.

S obzirom na složenost administrativno-političkog uređenja Bosne i Hercegovine od agresije naovamo, i muzejski zakonodavni okviri u Bosni i Hercegovini usitnjeni su te takvi da su vezani uz administrativnoteritorijalne cjeline, a jasnoći slike stanja doprinosi vrijedno izdanje Muzeja grada Zenice iz 2016. godine pod naslovom Muzejsko zakonodavstvo u Bosni $i$ Hercegovini od 1945. do 2012. godine priređivača Ikbala Coge, koje na sličan način kao u slučaju arhivskog zakonodavstva donosi pregled propisa, pravilnika, uredbi i uputa u vezi s muzejskom profesijom od njezine moderne institucionalizacije do novijeg vremena, čime jedino bibliotečka profesija $\mathrm{u}$ zemlji, među istaknutim baštinskim profesijama, barem zasad ostaje bez slične pregledne publikacije.

\section{Zaključne napomene ili Sinkretizmi još traju}

Historija baštinskih ustanova u Bosni i Hercegovini, kako u dugom periodu svoje predinstitucionalne faze, tako i danas, pokazuje sve odlike sinkretizma, međusobne povezanosti, međuuvjetovanosti te međusobnog naslanjanja jednih ustanova, odnosno jednih profesija na druge, čak i kada to u odsustvu komparativnog historijskog prikaza njihova razvoja te današnjice i nije najrazvidnije - čijoj vidljivosti ova studija ide u prilog - te će se i budući razvoj baštinskih ustanova u Bosni i Hercegovini zasigurno kretati u pravcu njihove snažnije sinergije te zajedničkih strategija opstanka i osnaživanja u svijetu punom izazova, čak i za statusno, ekonomski te uopće profesionalno snažnije zajednice. Ukoliko se svemu ovome doda pitanje neriješenog pravnog statusa nekoliko temeljnih baštinskih ustanova nacionalnog predznaka, uz posljedične probleme finansiranja, te već spomenutih praznina cjelovitog, formalnog akademskog obrazovanja u oblasti arhivistike i muzeologije - koje se pokušavaju nadomjestiti širim, generičkim okvirom informacijskih nauka kao akademskog područja, uočava se duboka diskrepanca između značaja, duge tradicije te izraslosti baštinskih ustanova te profesija, na jednoj strani, i nezavidnog položaja u kojem se trenutno nalaze, na drugoj strani.

Ipak, vidljivi primjeri sinkretizma još uvijek traju, bilo u djelovanju institucija kakve su odabrani bosanskohercegovački samostani, Gazi Husrev-begova biblioteka ili Zemaljski muzej Bosne i Hercegovine - kada su u pitanju institucije s višestoljetnom tradicijom - bilo, pak, u slučaju novog tipa sinkretske baštinske ustanove, kakav je, recimo, Bošnjački institut - Fondacija Adila Zulfikarpašića. Svemu valja pridružiti i profesionalno povezivanje i saradnju kakvu danas u Bosni i Hercegovini realizira Asocijacija informacijskih stručnjaka - bibliotekara, arhivista i muzeologa (BAM), slične zakonske regulative, dijeljenje ekspertnih znanja unutar zajednice baštinskih / informacijskih stručnjaka, dok su paralelizmi i povezivanja sve očigledniji i u naučnoj te strukovnoj publicistici, koja, očito, sve manje insistira na distinkciji između raznolikih baštinskih tema i fenomena.

Sva navedena zbližavanja i udružena djelovanja tri istaknute baštinske / informacijske ustanove i profesije kako kroz zajedničku prošlost, tako i u izazovnom trenutku današnjice dovoljan su povod za naučnu valorizaciju međusobnih odnosa i utjecaja, tim prije što će budućnost institucija sve naglašenije ovisiti o kolaborativnim modelima poslovanja, kako unutar baštinskog sektora, tako i prekosektoralno, o čemu već svjedoče iskustva širih evropskih i svjetskih zajednica. 


\section{Literatura}

- Anđelić, Pavao. 1970. Srednjovjekovni pečati iz Bosne i Hercegovine. Djela knj. 38, Odjeljenje društvenih nauka knj. 23. Sarajevo: ANUBiH.

- Babić, Anto. 1933. "Kancelarija bosanskih vladara" Napretkov kalendar za 1933, Sarajevo.

- Bašović, Ljubinka. 1986. Biblioteke i bibliotekarstvo u Bosni i Hercegovini 1918-1945. Sarajevo: Veselin Masleša.

- Bejtić, Alija. 1974. "Lični i kućni komfor u Bosni i Hercegovini XVIII vijeka” Jugoslovenski istorijski časopis 3-4: 147-167.

- Čeliković, Senad. 2019. Biblioteke i bibliotekarstvo u Bosni i Hercegovini: 1975-2010. Tešanj: Planjax komerc.

- Cogo, Ikbal, prir. 2016. Muzejsko zakonodavstvo u Bosni i Hercegovini od 1945. do 2012. godine. Zenica: Muzej grada Zenice.

- Čremošnik, Gregor. 1948-1951. "Bosanske i humske povelje srednjeg vijeka" Glasnik Zemaljskog muzeja u Sarajevu, nova serija 3: 103-144; 4-5: 105-200; 6: 81-119.

- Čremošnik, Gregor. 1976. Studije za srednjovjekovnu diplomatiku i sigilografiju Južnih Slavena. Građa knj. 22, Odjeljenje društvenih nauka knj. 18. Sarajevo: ANUBIH.

- Defter Darović, Ibrahim-beg. 1897. "Stare listine porodice Resul Begović" Glasnik Zemaljskog muzeja Bosne i Hercegovine 9: 193-226.

- Efendić, Nirha, Ibrahim Krzović, Almedina Čengić, i Lejla Kodrić Zaimović. 2018. Kratka historija kulture Bošnjaka. Sarajevo: Simurg Media: Internacionalni univerzitet u Sarajevu.
- Kožar, Azem. 2001. "Problematika obnove arhivske službe Bosne i Hercegovine" Arhivska praksa 4: 181.

- Kurtović, Esad. 2019. Arhivska građa za historiju srednjovjekovne bosne: (ispisi iz knjiga kancelarije Državnog arhiva u Dubrovniku 1341-1526). Sarajevo: Institut za historiju - Historijski arhiv Sarajevo.

- Lavić, Osman. 2013. "Biblioteke u Bosni za vrijeme osmanske vladavine" Magistarski rad. Sarajevo: Fakultet islamskih nauka.

- Lavić, Osman et al. 2017. Gazi Husrev-begova biblioteka: 480 godina postojanja. Sarajevo: Gazi Husrev-begova biblioteka.

- $\quad$ Leka, Alma. 2017. Muzeji, zbirke i galerije u Bosni i Hercegovini. Sarajevo: Udruženje ICOM - Nacionalni komitet Bosne i Hercegovine.

- $\quad$ Ljubović, Amir, i Lejla Gazić, ur. 2000. Orijentalni institut u Sarajevu: 1950-2000. Sarajevo: Orijentalni institut.

- Lorens, Vešler. 1998. Kabinet čuda gospodina Vilsona. Beograd: Clio.

- Rodinis, Andrej. 2004. “Arhivska služba Bosne i Hercegovine: povijesni razvoj i perspektive” Magistarski rad. Zagreb: Sveučilište u Zagrebu.

- $\quad$ Šehović, Amira, i Džemila Čekić, prir. 2007. Zbirka arhivskih propisa Bosne i Hercegovine: 1947-2007. Sarajevo: Historijski arhiv Sarajevo. 


\title{
SYNCRETISMS OF HERITAGE INSTITUTIONS IN BOSNIA-HERZEGOVINA: CONTRIBUTION TO SCIENTIFIC VALORISATION OF THEIR HISTORICAL AND CURRENT RELATIONSHIPS
}

\begin{abstract}
Tradition but also the current practice of heritage institutions in Bosnia-Herzegovina show, as their continuous characteristics, similar developmental patterns, but also complement current practices between the most prominent representatives of heritage institutions of today - archives, libraries and museums. Converged practices of heritage institutions are found throughout their whole history, both at the general, global level, but also at the Bosnian-Herzegovinian, particular level. Despite the obvious parallelisms, but also specifics in tradition and activities of heritage institutions in Bosnia-Herzegovina, in Bosnian-Herzegovinian sciencepublishing there is an obvious gap in comparative studies related to interrelations between the most developed heritage institutions of this area, in their diachronic but also synchronic perspectives. Despite the fact that unique historical origin but also later reliance and convergence between these institutions are obvious in the case of the past of Bosnian-Herzegovinian libraries, archives and museums, actual institutions' syncretism is even more obvious today - often encouraged by changes in wider information and communication environment, but also by changed users' expectations. An interdisciplinary notion of syncretism in this paper is used in its metaphorical sense, describing processes of the development of heritage institutions from their common origins, but also their later convergence trough processes such as: replacement role of one heritage institution until the establishment of the other one, joint storing of heritage materials without institutional division, integrated activity of archives, libraries and museums "under one roof", all the way to the joint digitization projects, gathering heritage profession under joint professional organizations, as well as, at the end, the joint academic degree programmes, which, under the generic term of information sciences, are integrating these three prominent heritage disciplines within this framework. Therefore, the paper aims to contribute to the scientific valorisation of interrelations between Bosnian-Herzegovinian heritage institutions, both in the past and present time.
\end{abstract}

Keywords: heritage institutions, archives, libraries and museums, syncretisms, parallelisms, BosniaHerzegovina 